\title{
Role and limitations of NGOs in partnership with the state
}

\author{
Joaquim Fontes Filho \\ Fundaçao Getulio Vargas
}

\begin{abstract}
The new paradigms of public administration are strongly based on greater interaction between the state, private sector and society through actions based on networks, co-production, and collaborative governance. However, several characteristics of civil society organizations or non-governamentals organizations (NGO) bring limitations to an effective long-term partnership. This paper aims to describe and analyze the limitations of NGOs that may affect these partnerships and the nature of this organizations, with reference to the Brazilian context, since the institutional environment and regulatory framework is critical to understand these limitations. Based on a meta analysis in former studies that assessed the relationship between NGO and the state, it was possible to point as the main problems for the NGOs from this relationships.
\end{abstract}

Keywords: State-NGOs relationship, New Public Governance, Collaborative governance, manufactured society. 


\section{Introduction}

The new paradigms of public administration are strongly based on greater interaction between the state, private sector and society through actions based on networks, co-production, and collaborative governance. However, several characteristics of civil society organizations or non-governamentals organizations (NGO) bring limitations to an effective long-term partnership. Partnerships between the state and NGOs may distort the very nature of these organizations as representative of interests of society, as it may reduce their advocacy role, their financial independence, their accountability orientation and the perception by the attended public as different from the state, not a part of it (manufactured society). This paper aims to describe and analyze the role, characteristics and limitations of NGOs when operating these partnerships, with reference to the Brazilian context, since the institutional environment and regulatory framework is critical to understand these limitations.

Despite numerous proposals of several authors, there is no universal taxonomy for classifying the various types of NGOs in the broader set of third sector organizations. In Brazil, 300,000 organizations are classified in official statistics as NGOs, characterized as private, nonprofit, voluntary, selfmanaged and targeted at improving the quality of life of unassisted population. For a significant portion of these organizations, however, government resources are critical to its operation, especially after the international economic crisis of the late 1990 s, although they can may reduce their freedom of action and political independence from the state, and redirect the accountability of NGOs to the government-contractor and not to the populations served. Identified by Hodgson (2004) as 'manufactured civil society', this relationship can damage the identity of the NGO and produce a mixture between the state and voluntary sector organizations.

The possibility of accessing public funds may also stimulate a political capture, when NGOs become propagating the ideas of political groups, sacrificing, in this role, their ability to critique the actions of the state. Another problem is the foundation of NGOs by politicians or their families only to facilitate or legitimize access to public funds under their management.

An important discussion about the state-NGO relationship refers to the possibility of masking, in fact, a process of outsourcing by the state. To escape the restrictions of hiring staff or services, agreements with NGOs could be used to meet demands without increasing fixed costs or size of the state, with gains in speed and flexibility in hiring. But, of course, it brings many problems and pitfalls for the NGOs.

The 300 companies listed on stock exchanges in Brazil are subject to intense scrutiny by the market, investors' associations and government agencies. This external control, however, is impractical for NGOs. Besides being about 300 thousand in Brazil, there is a wide variety of legal types, field of activity, size and skills, making it virtually impossible for the external control exercised by the state or other actors. According to Weidenbaum (2009), NGOs charges accountability of companies and governments, but rarely has mechanisms of governance to be accountable for their own activities. In turn, the proposals of collaborative governance and New Public Governance write about the importance of tacit contracts, reducing the formality in relations between the parties involved. Therefore, there remains the challenge of easing relations between the state and civil society organizations without reducing the independence and nature of the NGOs or create spaces for irregular or illegal actions by the actors.

In order to analyze the role and characteristics of NGOs in partnerships with the state in Brazil, it is first discussed the concept and classification of NGOs, the new paradigms in public administration that review the importance of the relations NGO-state, and then investigate what happens in the Brazilian context based on a revision of several recent studies that assessed this issue.

\section{How paradigms changed in pu- blic administration}

Public administration (in a broad concept), as well as public management (the efficient search of the goals proposed by the administration and political system), are two fields that have to go through strong adaptations to respond to changes in the demands of the society, whenever technology, economy, political environment and other aspects deliver new possibilities for the state to capture, understand and attend the expectations of the society.

The idea of paradigms, as proposed by Kuhn (1970), refers to a set of ideas or articulated scientific achievements that drive models that are the basis for the research problems in a particular field of knowledge or a group of researchers, or the technical certainty and consensus characterizing a field of study (Pfeffer, 1993). In Kuhn's words, paradigms 
are "universally recognized scientific achievements that for a time provide model problems and solutions for a community of practitioners" (1970: viii).

$\mathrm{Lu}$ (2013) uses the development of Kuhn to discuss the paradigms in the field of public administration, recalling the self-doubt in this author to expand its use from the natural sciences to the social sciences, noting however that in most social sciences it is rare to observe the paradigm shift, but is frequent a "parallel paradigm", that is, the coexistence of several competing paradigms.

Even if taking a less rigid approach to the concept of paradigm, its employment to locate the changes in the set of ideas, assumptions and propositions in the field of public administration is useful to systematize the different movements that prevailed over the past few years. Lu (2013) also mentions the six successive paradigms that public administration theory went through as identified by the Henry (2010) of the politics / administration dichotomy (1900-1926), principles of public administration (1927-1937), public administration the political science (1950 to 1970), the public administration management (1950-1970) public administration the public administration (1970-present) and governance (1990-present). Interestingly, using similar reference to assess changes in public administration in Brazil -context that will later be used for analysis- Keinert (1994) observed an interrelation of these ideas, or paradigms, mainly from the mid-twentieth century, although with the evidence of a time lag translating them into this national context.

Presenting the New Public Management (NPM) as a new set of ideas and differentiate their doctrinal components of those present in other sets of practices of public administration, Hood (1991) placed a new paradigm, from an opposition to the bases of the previous paradigm, and positioned a landmark that has served as a beacon to the ideas in this field. The NPM is understood as a response to the dysfunctions of bureaucracy, and later movements as a response to the concerns about 'new public management' (O'Flynn, 2007).

Pestoff (2011) proposes that each paradigm in public administration is associated to a particular ideology and historical period, and must be seen as competing and layered realities that co-exist for politicians, managers and in the academic and public discourse. He uses the citizens' perspective to propose that changes in their roles, in the relationship with the state, are connected with the evolution of the paradigms. At first, citizens were described as passive users or beneficiaries of the public administration, under the scope of the traditional public administration ideology. Then, they turned into customers, with some voice in the scope and content of services, in the era of the New Public Management. More recently, citizens are seen as co-producers, responsible for playing a more direct role in the provision of services, in the so-called Networked Governance paradigm.

Many authors divide the paradigms of public administration around three different moments, similar to those proposed by Pestoff (2011). Osborne (2006) is one of this authors. For him, the hegemony of Public Administration, which last from the late nineteenth century through to the early 1980s, was replaced by the NPM paradigm and the assumption that the application of managerial techniques to public services would bring improvements in the efficiency and effectiveness of these services, and now we see the emergence of a new paradigm called the New Public Governance (NPG). According to Pestoff (2011), New Public Management (NPM) is based on active service consumers and contracting out through public private partnerships, and New Public Governance (NPG) is based on co-production, multi-stakeholder governance and third sector provision of welfare services.

Osborne (2006) sheds light in an increasingly inter-organizational nature of public management, which involves a huge increase in the number of actors involved in policy formulation and implementation. He points as the main characteristics of NPG the strengthening of institutional relations with society; networks between organizations within and outside of government to provide public services; relationships based on trust and relational contracts (a contract whose effect is based on a relationship of trust between the parties); state understood as a plural body; New Public Governance based on sociological theories and networks

In parallel to changing paradigms, theories and associated epistemological bases also migrate from a rationality based on formalism, legal, and definition of operational standards to a rationality dominated the quest for efficiency and coordination. The main change to the paradigm of network and governance in public administration refers to a greater participation and representation of stakeholders in the design, construction and production of public policies. Therefore, the new models are rooted within organizational sociology and network theory (Osborne, 2006), not in the logic of public choice and agency theory. 


\section{Classifying NGOs}

According to DiMaggio y Anheier (1990), the nature of the activity "nonprofit" does not have a trans-historical significance or transnational, as the functions, origins and behavior in this sector reflect specific legal definitions, cultural heritage and public policies of different nations and societies. This observation refers to the difficulty in generalizing international learning and appropriate them directly to the national reality (Carver, 2001; Cornforth, 2003; Lee et al, 2008; Malo, 2006; Ruys et al., 2007). Thus, the absence of recognized standards to propose a classification of its structures and practices, and to allow adequate international generalization may constitute a difficulty to evaluate the effectiveness of the NGOs contribution and thus impede access to government resources or other donor organizations or donor.

The development of classifications for organizations in the third sector is challenging, as there is no general consensus related to what is its definition. Actually, Pestoff \& Brandsen (2009) afirm that the third sector may have many different names, such as the voluntary sector, the non-profit sector, the social economy, civil society, and many others with a large degree of overlap. Hudson y Bielefeld (1997) consider that international research on nonprofits is difficult because what constitutes this nonprofit sector varies greatly across countries, and are named as different as nongovemment, paragovernment, private voluntary, and community associations, and assume as many form as foundations, corporations, associations, and so on. However, there is some consensus that they are located between the state and the for-profit sector.

Vakil (1997) states that the lack of consensus in defining and classifying the nongovernmental organizations (NGOs) inhibits the possible theoretical and empirical advances to understand how NGOs function, for which he proposes a classification.

Not only the field of NGOs demand appropriate models or classification structures, but also some constructs used in studies of these organizations. To Lima Neto (2013), the NGOs, according to a general definition, it can be considered as civil society itself proxy. To Mitchell (2014), civil society must be understood as a complex construct with multiple interpretations, with ambiguity and contradiction, with the diverse perspectives of an arena of Tocquevillian of "associational life," as an Aristotelian "good society" and an Habermasian deliberative "public sphere".

\section{Main models of relationship State-NGOs in Brazil}

The Brazilian Institute of Geography and Statistics (IBGE) is responsible for mapping the private foundations and non-profit organizations in Brazil, which is disclosed in the document FASFIL (stands for Private Foundations and Non-Profit Associations). FASFIL defined third sector organizations following the methodology presented in the Handbook on Non-Profit Institutions in the system of national accounts, issued by the United Nation and the John Hopkins University, in 2002, in order to permit international comparisons. In this sense, to be included in the sample organizations must meet five criteria: Organized, i.e., institutionalized to some extent; Private, i.e., institutionally separate from government; Self-governing, i.e., equipped to control their own activities; Nonprofit-distributing, i.e., not returning profits generated to their owners or directors; Voluntary, i.e., involving some meaningful degree of voluntary participation.

Three types of organizations meet these criteria, under Brazilian law: associations, foundations and religious organizations. While an association is formed by the union of people and is organized for non-economic purposes, the foundation is created by a settlor who allocates resources to compose its equity, specifies the purpose for which it is intended and how to manage it.

The study identified 290,700 organizations officially registered in 2010 . They represented $5.2 \%$ of the total of 5.6 million public and private, profit and non-profit entities registered in the Central Register of Enterprises (CEMPRE), and included 28.5\% predominantly religion-based, $15.5 \%$ employer and professional associations, $14.6 \%$ development and protection of rights and $18.66 \%$ in the areas of health care, education, research and social welfare (governmental policies). Another study conducted by Brazil's Institute of Independent Auditors indicated that the volume of resources handled by the third sector in Brazil accounted for about 5\% of gross domestic product (Instituto dos Auditores Independentes do Brasil, 2011: 20).

The analysis of the available data in FASFIL indicates that the prime aim of the non-profit foundations and organizations is to protect citizens' rights and interests and disseminate religious precepts. However, the slight rise in the average of employees in these organizations, from 6.9 in 2006 to 7.3 in 2010 should be analyzed bearing in mind the high degree of informality regarding employment relationship, so that this figure might be significantly 
higher.

In 2010, there were, on average, 7.3 salaried employed persons per entity, with variations of 224.8 workers (in hospitals) to 1.8 workers per entity (in religion). However, in $72.2 \%$ of NGOs there was not even a single formal worker registered for the year of 2010, which suggests that they are strongly supported by volunteer work and freelance services, possibly with a low degree of formalization and little capacity to participate tenders and bids for access to third-party resources, including the state.

Despite this coverage in operations and economic and social impact, NGOs need to be improved in terms of transparency, legal certainty, and quality of external controls by the lack of operational capacity of the covenants. The absence of a clear regulatory framework leaves the organization under the discretion and the jurisprudence of the courts of auditors responsible for overseeing these organizations (Coelho, 2013). In addition, this regulatory absence implies a low standardization in governance settings and organizational practices used by these NGOs. The models of board, selection of board members, collective decision practices, goal setting for structures, rendering of accounts, transparency and accountability, project selection and management structures have very different ways and patterns between these NGOs, inhibiting the evaluations of advantages or disadvantages of the different configurations, and reducing the efficiency of government and social performance control.

The development of the third sector in Brazil, while activity carried out by a private law organization in order to develop initiatives to the public interest, appears initially in the sixteenth century. Because of the strict link with Portugal, the appearance of the first social support structures takes place through private religious institutions and of individual voluntary initiatives that reflected the conservatism of an elite society (Graef y Salgado, 2009). In a sense, the establishment of social assistance was associated, from the seventeenth century to the $1930 \mathrm{~s}$, to the notion of charity and donations for the "disadvantaged population".

These activities were practiced by altruistic individuals or religious appointed institutions. It was only during the government of Getulio Vargas government, in the 1930 's, that the State assumed responsibility, albeit in a patronizing manner, of the issues related to social assistance. It stands out in this period the creation of the National Social Service Council in 1938 and, years later, in 1942, the Brazilian Legion of Assistance - LBA. Social assistance as a right was only officially designated as a responsibility of the State in the new Federal
Constitution, in 1988, when it reached the status of social right guaranteed by the allocation of public budget funds of social security among other sources (Article 203 IV, Article 204, I and II).

Although the role of the State as responsible for social welfare activities was made official by the Federal Constitution of 1988, its activities in the exercise of this responsibility could never exceed the limits of education and health fields, which gave rise to the establishment of several institutions that began, themselves, to meet the social needs not covered by the state.

It was only with the Federal Constitution of 1988 that the social care was recognized as a social right, although there have not been implemented measures to guarantee this recognition, mainly due to the strong conservative influence that subsists in the country, expressed in paternalistic practices adopted by government agencies and in the power of the philanthropic entities, who sits on the survival of the oligarchies and in the huge welfare structure. The fact is that apart from the health and education sectors, the Brazilian government never acted, in fact, in the social area, which gave rise to the establishment of the network of welfare institutions, linked mainly to the churches, especially the Catholic Church, builded up over five centuries of history of the country (Graef y Salgado, 2009).

These institutions, according to the Brazilian Civil Code (Law No. 10.406, of January 10, 2002 Article 44), legal framework that deals with the legal status of organizations in general (but not corporations), are characterized as legal entities of private law and are contained in the environment of nonprofit organizations. The concept of third sector has begun to be addressed in the first half of the twentieth century in the United States as a combination between the public sector, represented by the State and the private sector, highlighting the already discussed difficult to define given the multiplicity of organizations such as associations, foundations, political parties, clubs, non-governmental organizations (NGOs), civil society organizations of public interest (OSCIP), among others, possessing purposes and distinct natures, often unrelated to each other (Graef y Salgado, 2009). The key point is that NGOs are not companies and neither are part of the state structure, subject to public law).

The Civil Code also provides that in cases provided by law NGOs can have a different legal regime, receiving for example the Social Organization attribute (OS) or Civil Society Organization of Interest, conditions that allow them special situations in contracts with the State. 
NGOs can establish a legal relationship with the State by contract or agreement, which are quite distinct instruments. In the agreement, the reciprocal interest and mutual cooperation prevails, both parties ? NGOs and state? aims common institutional goals, and the remuneration is made in advance, being forbidden the presence of any profit. In the contract, the goals are private and contradictory, the contractor expects to receive the good or service and the hired the remuneration, with the remunration made after delivery of the good or service, accepting profit.

Although the regulations and the limited current regulatory framework establish purpose, rules of operation, supervision and internal monitoring tools, this regulatory set rises a diffuse control, fragmented and disjointed in different instances in the conduct of modes of governance of these organizations. This is more significant especially considering that there are three government instances in the country ? federal, state and municipalities ? all authorized to perform contracts with NGOs, and the regulation is still fragile especially with regard to contracts for the states and municipalities.

Is worth noting that the installation process and maturation of activities of NGOs in Brazil is strongly linked to the political process. The Brazil lived under a regime or dictatorship in the period from March 1964 to January 1985, with the election, indirect, of a civilian president. As analyzes Thomas (2009), during this period the work of social movements was strongly marked by the joint against the state, around the democratization of the country and the achievement of various social rights and against censorship of expression and communication.

With democratization, there was a change of direction and operation of NGOs, with increasing professionalization and quantitative and geographic expansion. NGOs started to compete for resources and government contracts, and to seek a more entrepreneurial logic of operation, as well as greater support and credibility in society.

This social support brought not only legitimacy but also resources for projects. With the international crisis of the late 1990s and the improvement of the country in international economic rankings the country turned into an exporter of resources, not more receptor, leading national NGOs to seek new sources of revenue, either by contributions and donations of society or state resources.

According to Thomas (2009), the role of NGOs have been held in the provision of social services for reasons of "alleged" operational agility and trans- parency of costs, and for bringing greater involvement of organized society. However, this is leading to an appreciation of utilitarian nature, since the engagement of NGOs allows handle unsatisfied social demands and the decrease in government spending and the range of social programs, reducing pressure on the government. And summarizes the current situation of the relationship between social movements, NGOs and State with the statement made by Montaño (2003: 273), for whom "from the struggle (of the social movements), one passes to a moment of trading (between NGOs and state), followed by the management of conflicting interests (people's organizations), and then to a patronage relationship."

\section{Characteristics and limitations in the relationship State-NGOs in Brazil}

To study the main characteristics and limitations of NGOs that may affect these partnerships, with reference to the Brazilian context, it was developed an analysis and reflection based in former studies, especially related to the Brazilian context, that assessed the relationship between NGO and the state, limited to those that are developed under a formal contract.

A set of 25 articles published in academic journals on topics related to the relationship between NGOs and the State in Brazil were selected for analysis and collected, as well as a set of 42 newspaper articles and journals since 1990 that directly or indirectly dealt with these issues. The collection did not follow a structured process, being the guided collection by the prioritization of the articles in consultation in the systems Google and Google Scholar. The reading of the texts guided, in an inductive way, the main aspects of the analysis.

The expression that best synthesizes the relationship between NGOs and the state in Brazil is presented by Lima Neto (2013): "a partnership with the state is a two-way street", as it allows enhance the results of NGOs and simultaneously brings a series of obstacles and bureaucratic constraints that compromise their autonomy. Based on interviews with 50 NGO managers seeking to understand their auto perception of profile and performance, Lima Neto (2013) noted that NGOs consider that the interaction or conflict with the state is something almost inevitable in their everyday chores, as both share similar social functions, but their agility, flexibility and proximity to the target audience, seems sufficient to a more individualized monitoring. At 
this point, it is interesting to use the ideas of NPG about the importance of using partnerships with NGOs for the state to increase their ability to understand and deal with a fragmented set of social demands. The NGOs also perceive themselves as less vulnerable to political influence and therefore more independent.

Regarding the partnerships with the state, respondent leaders understand that bring many benefits and certainly problems. The partnership allows better understanding of the functioning of public administration, and brings credibility and visibility to the NGO. It also allows expanding its range of operations to other audiences and places and especially increasing the fundraising. Downsides would be the bureaucracy of the state, with overly burdensome requirements for accountability and participation in public notices. Other problems would be government interference, delays in payments, stiffness spending and especially the discontinuity of the actions caused by government changes.

It is interesting to contrast the perception of leaders for contracts with companies. These are seen as much less bureaucratic, mainly because companies are concerned with results rather than procedures, and greater mobility in the application of resources. However, for many respondents such partnerships can bring negative impacts to the image and reputation of NGOs, to be eventually perceived as advertising tools or marketing companies, in addition to the companies expect quantifiable results and are less sensitive.

The weakness of the legal framework has also brought serious problems also for NGOs-state relations, especially the possibilities of political capture by interest groups, and detours of its purpose. In this sense, between 2007 and 2010 the National Congress conducted an investigation (the Parliamentary Commission of Inquiry) on money transfers occurring by the federal government to NGOs linked both to the government itself as the allied political parties, according to the suspects agreements between the federal government and such entities were being used as a means of diverting public money. In the end, the investigation was completed and generated a report with more than 1,478 pages, but that ended shelved without direct consequences, but it certainly cast doubt on the state of the partnership with the NGOs.

Ojeda (2012) analyzes that these accusations placed focus on the lack of adequate control and supervision over the work of NGOs, especially given the major growth of public funds they received. In addition to financial problems, criticism was that some sort of outsourcing of the State activities and responsibilities to society was taking place. Based on the analysis of other authors, he also states that during the period of dictatorship NGOs were observed virtuously, since they represented a tool of social issues resolutions and claiming, but like any other organization they may incur in managerial problems, or be influenced by partisan political logic, present in various entities supposedly nonprofit. Moreover, in the words of one NGO leader about why parliamentary investigations have not advanced, "For almost every deputy has your NGO. The parliamentary amendments are for it. It is a way to create the electoral corral. I will not say all divert money. But they serve at least to create their stronghold."

Carrying out a case study in a NGO with more than 50 offices in the country, and working in the development area and emergency programs, Ckagnazaroff and Souza used as an analytical layout the differentiation proposed in Lewis (2001) between active partnership when the NGO has certain autonomy of action and can discuss the project with the state, sharing risks and capable of learning and information exchange, the dependent partnership, where the state sets the project to be pursued, with no room for discussion, predominantly top-down guidance, rigid roles based on the comparative advantages of actors, and individual interests.

The authors observed that those partnerships that left a closed project from the state government, top to bottom, had focused on a particular policy or government demand, getting the NGO responsible only for the execution of tasks, and limited the methodological choices, once the choice of participatory methods was not accepted by the government agency, which adopted a paternalistic and centralizing stance. In addition, they understand that there was a risk of co-optation of NGOs by the state government.

In general, they analyzed that the state-NGO partnerships brings problems in four aspects. First, for the budgetary constraints and extra costs due to state delays. Second, the administrative continuity of the state could have the effect of interrupting projects and bring in frustration to the community and harm the image of the NGO. Third, shocks due to differences in culture, as members of NGOs may be perceived as more motivated to get the job done and civil servants as working for further financial gain through overtime. And fourth, as the difference in the operating mode when the bureaucracy of State organs may hinder the progress of projects.

Assessing the nature of relations between Environmental NGOs and the state in one unit of the federation, Thomas (2009) assumes that, since the 
1990s, decentralization of activities by the Brazilian government has contributed to increase the sharing of responsibilities towards solutions to social problems, and NGOs perceived as intermediates in their relationship with civil society and as a effective executors projects, which justifies delegating public functions to entities belonging to various social movements. It is interesting to observe, in this study, that are compared two NGOs created at different times, the first in the early 1980s still during the dictatorial situation in the country and the second in 1990, already during the resumption of the democratic stage. While the first adopted a highly critical position to the partnerships with the State, the second had partnerships exactly as an operational strategy.

The history of these two entities is quite different, but in general converging for greater professionalism and access to public and private resources. As for the oldest NGOs, there appears to be a hard time accepting this new situation, since they point to the paradox that while environmental issues and demands for social mobilization are growing, voluntarism and militancy have decreased, moreover the use of money from financiers decreases the denunciation's acting capability and social struggle. In addition, the use of these resources produces a fragmentation on the expectations of leaders and activists about their impact on the autonomy of the body against the government and funding agencies.

For the youngest NGO, the volunteer figure does not exist, being considered as "complicated", since it cannot be demanded, as it has no formal link. The NGO has been created in the professional model, unlike the first, does not guides its action by confrontation but by the quest for reconciling interests.

Assessing the recent history of the relationship between NGOs and state in Brazil, the numbers show that since 1990 there has been both a significant increase in the number of NGOs and the volume of public funds they receive.

\section{Final remarks}

Situation analysis of NGO-State relationship in Brazil identifies circumstances that can be of benefit to the state, but can also bring harm to NGOs in the medium and long term. Moreover, these losses should not be attributed only to individual organizations, but to the entire system and, ultimately, to the very credibility of NGOs in society.

As seen, the partnership with the state is for the
NGO the possibility of establishing a strategic partnership that enhances their results, but simultaneously has a number of bureaucratic obstacles and impediments that can compromise their autonomy. In a way it is possible to even question the assertion of the authors analyzed, for whom the partnership of NGOs with the state is a two-way street, since it is perceived by managers both as a major obstacle to its operations but also as a lever for projects of NGOs. Perhaps what is predominating in these partnerships is outsourcing process by the state, to which the NGOs are accommodating.

Actually, a former study in a Brazilian state which analyzed partnerships from the government with civil society organizations showed the predominance of agency-type partnerships and the centrality of the government and a techno-bureaucratic role in fostering and maintaining the NGOs, what they call as an "invasion" of manufactured civil society (Peci et al., 2011).

For the state, within the NPG logic, it is certainly important to rely on the reach of NGOs and proximity to target populations, allowing certain individuality in the treatment of demands. However, local flexibility and proximity of these NGOs can, over time, become contaminated by the state bureaucracy, mimicking their processes and becoming quasi-public organizations.

The critical point is noted that the partnership can increase the dependence of the NGO regarding public resources, eventually harming the focus of their actions or accountability. Thus, the NGO becomes more concerned with meeting the demands of the government that the society in which it operates, and directing their accountability to the government (and not the company). Moreover, this dependence can create a concern for "not complete the services and extinguish the problem" in order to continue to receive public funds or give rise to opportunistic interests to perpetuate trouble to keep their financed.

Access to public funds may also stimulate political capture and reproduction of dominant ideologies. Recently, trade union movements and student organizations were accused of promoting demonstrations in favor of the government because of a political capture (Magnoli, 2015), and former Brazilian President threatened to call the social movements of the landless to hold demonstrations, as an "army" to defend the government (Haubert, 2015).

Finally, the perspective of the state partnership with the NGOs can be full of benefits, these benefits have yet to be evaluated further. There remains the challenge of easing relations between the state 
Figure 1: Union transfers to NGOs (in Brazilian Reais)

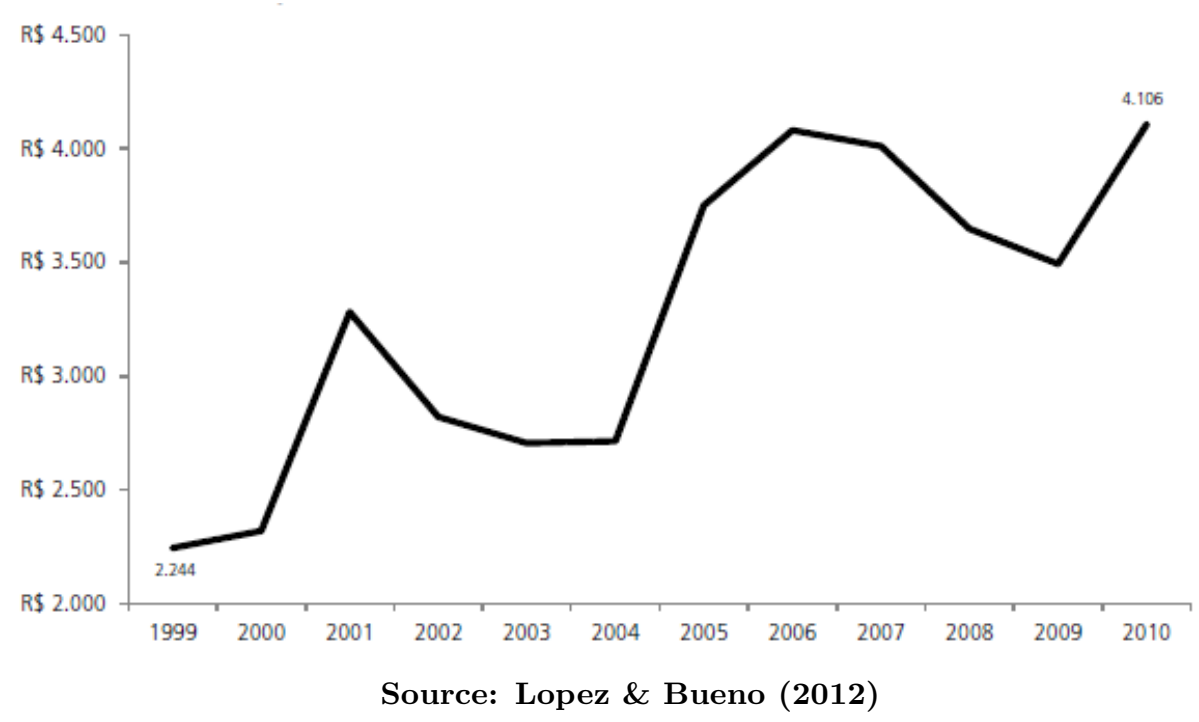

and civil society organizations without reducing the independence of the company or create spaces for irregular or illegal actions by the actors.

\section{References}

Carver, J. (2001). Carver's Policy Governance@) Model in Nonprofit Organizations. Gouvernance: Revue Internationale, Hiver, 2(1):30-48.

Coelho, M. (2013). Comissão discute em seminário novo marco regulatório para as ONGs.

Cornforth, C. (2003). The governance of public and non-profit organizations. Routledge.

DiMaggio, P. y Anheier, H. K. (1990). The sociology of nonprofit organizations and sectors. Annual review of sociology, 16(1):137-159.

Graef, A. y Salgado, V. (2009). As relações com as entidades privadas sem fins lucrativos no Brasil. Anais do $14^{\circ}$ Congresso Internacional do Centro Latinoamericano de Administración para el Desarrollo, pp. 27-30.

Haubert, M. (2015). Comissão da Câmara quer que Lula explique fala sobre 'exército de Stédile'.

Hodgson, L. (2004). Manufactured civil society: counting the cost. Critical social policy, 24(2):139-164.

Hood, C. (1991). A public management for all seasons? Public administration, 69(1):3-19.

Hudson, B. A. y Bielefeld, W. (1997). Structures of multinational nonprofit organizations. Nonprofit Management and Leadership, 8(1):31-49.
Instituto dos Auditores Independentes do Brasil (2011). Terceiro Setor Caminha para a Maioridade: Entidades se alinham cada vez mais às boas práticas contábeis. Revista Transparência, $1(2): 20-25$.

Kuhn, T. S. (1970). The structure of scientific revolutions. University of Chicago Press, Chicago.

Lewis, D. (2001). The managemant of NonGovernamental Development Organizations. Routledge, London.

Lima Neto, F. (2013). Relação com o Estado na visão das ONGs: uma sociologia das percepções.

Lu, J. (2013). Intellectual Paradigms in Public Administration: Why So Many and How to Bridge Them? Administrative Theory 8 Praxis, $35(2): 308-313$.

Magnoli, D. (2015). O meio e a mensagem.

Malo, M.-C. (2006). The variety of governance and management configurations: the case of third sector organizations. CRISES.

Mitchell, G. E. (2014). Collaborative propensities among transnational NGOs registered in the United States. The American Review of Public Administration, 44(5):575-599.

O'Flynn, J. (2007). From new public management to public value: Paradigmatic change and managerial implications. Australian journal of public administration, 66(3):353-366.

Ojeda, I. (2012). A complexa relação entre Estado e ONGs. Revista Desafios do Desenvolvimento Ipea, 71 . 
Osborne, S. P. (2006). The New Public Governance? Public Management Review, 8(3):377389 .

Peci, A., Figale, J., y Sobral, F. (2011). The invasion of manufactured civil society: government nonprofit partnerships in a brazilian state. Public Administration and Development, 31(5):377-389.

Pestoff, V. (2011). Co-production, new public governance and third sector social services in Europe. Ciências Sociais Unisinos, 47(1):15.

Pfeffer, J. (1993). Barriers to the advance of organizational science: Paradigm development as a dependent variable. Academy of management review, 18(4):599-620.

Ruys, P. H. M., Bruil, J., y Dix, H. (2007). Modes of governance in the Dutch. Annals of Public and Cooperative Economics, 78(3):381-413.

Thomas, E. (2009). A Natureza das Relações entre ONGs Ambientalistas e o Poder Público Estatal: o estudo comparativo de duas organizações baianas. En XXXIII Encontro da ANPAD, São Paulo.

Vakil, A. C. (1997). Confronting the classification problem: Toward a taxonomy of NGOs. World development, 25(12):2057-2070.

Weidenbaum, M. (2009). Who will guard the guardians? The social responsibility of NGOs. Journal of Business Ethics, 87:147-155. 